\title{
Nitrogen and Phosphorus Removal from Sewage in Biofilter - Activated Sludge Combined Systems
}

\author{
Andrzej Wałęga, Krzysztof Chmielowski, Dariusz Młyński* \\ Department of Sanitary Engineering and Water Management, University of Agriculture, Kraków, Poland
}

\author{
Received: 19 February 2018
}

Accepted: 11 April 2018

\begin{abstract}
Our paper analyzes nitrogen and phosphorus removal from sewage in a biofilter. The analysis was based on the multi-variant simulations of the combined system: fixed-film - activated sludge performance. An activated sludge ASIM $2 \mathrm{~d}$ model related with the model of pollutions' transformations in fixed film was used for the calculations. The results of exploitation analyses performed on the objective treatment plant - average daily rate of wastewater, $\mathrm{pH}, \mathrm{COD}$ values, total suspended solids, total Kjeldahl nitrogen, nitrate nitrogen, total phosphorus, and alkalinity - were used as input parameters for the calculations. The results indicated that there is a possibility of including fixed-film in the activated sludge technology in order to improve nitrogen and phosphorus removal from the sewage. The nitrification process will be performed in fixed-film, whereas nitrogen and phosphorus removal from the sewage will be performed in anoxic chambers, which operate in the activated sludge technology. Denitrifying the dephosphatation process guarantees the high level of total phosphorus reduction (81\%) and the $42 \%$ total nitrogen reduction, but only if the whole easily decomposable substrate will be consumed by microorganisms in the anoxic chamber and if enough nitrates will be present in the environment.
\end{abstract}

Keywords: household sewage, activated sludge, fixed-film, denitrifying dephosphatation, mathematical model

\section{Introduction}

According to the requirements of the current Minister of Environment Regulation from 18 November 2014, not all sewage treatment plants achieve the required level of pollution reduction [1]. The only way to adjust these objects to current standards is their complex modernisation. Treatment plant modernisation

*e-mail: dariusz.mlynski@urk.edu.pl means liquidation of biofilters. Normally a designer does not see the possibility of including biofilters into a biological dephosphatation scheme coupled with nitrification and denitrification. The possibility of integrating biofilters and activated sludge to intensify biogenic compound removal from the sewage occurred when bacteria capable of denitrifying dephosphatation were identified $[2,3]$. Bacteria that accumulate phosphates may be divided into two groups: bacteria that accumulate phosphates from sewage with oxygen as an electron acceptor and with nitrites as electron 
acceptors [4-9]. The first one belongs to a classic anaerobic-aerobic system whereas in the second case phosphorus is removed in anaerobic-anoxic zones. Denitrifying dephosphatation allows for elimination of oxygen chamber. In such a system competition between microorganisms is directed toward the predomination of bacteria capable of dephosphatation in anoxic conditions. By avoiding unnecessary aerobic usage of organic compounds, the denitrifying potential of the system increases and enables effective sewage dephosphatation with low $\mathrm{BOD}_{5} / \mathrm{P}$ ratio. Closing dephosphatation in an anaerobic-anoxic cycle allows for separation of nitrification and a dephosphatation system, and conducting it on isolated biofilters or on a separate part of activated sludge [10-12]. Dephosphatation can be also effective when nitrites act as electron acceptors. However, they cannot occur in too high concentrations due to their inhibiting influence on the process of excessive phosphates intake by microorganisms, which continues even after the cessation of $\mathrm{NO}_{2}-\mathrm{N}$ dosage into the sludge. According to Huang et al. [13], a critical concentration of nitrite nitrogen in an anoxic chamber should not exceed 5,0-8,0 $\mathrm{mgN}-\mathrm{NO}_{2} \cdot \mathrm{dm}^{3}$. Separation of nitrification beyond the traditional system leads to increasing the percentage of nitrifiers in biomass, thus increasing in productivity of this process $[14,15]$. The introduction of nitrification on biofilters into activated sludge systems allows for more effective nitrogen removal in low temperatures without the necessity of increasing the volume of the oxygen chamber [16-19]. Removing a higher amount of organic compounds in anoxic conditions stands for deeper denitrification and in consequence reducing energy consumption for aeration and lower production of excess sludge. The process of denitrifying dephosphatation is possible in flow and cyclically operating systems. Research on denitrifying dephosphatation in an SBR reactor carried out by Styka [20] showed that due to the introduction of an anoxic phase in the middle of the aerobic phase in an anaerobic-aerobic SBR reactor with quick filling, the fraction of denitrifying bacteria phosphate-accumulating organisms (PAO) increased from 15,9 to $44 \%$ of the total number.

The DEPHANOX (ANOXic DEPHosphation) system is an example of practical realisation of nitrification separated on biofilter in a flow system [21-23]. This system reduces general phosphorus by $71 \%$ with 7,8 $\mathrm{mgP} \cdot \mathrm{gsmo}^{-1} \cdot \mathrm{d}^{-1}$ of its intake, whereas the efficiency of nitrate nitrogen reduction reached about $60 \%$ with $30 \mathrm{mgNO}_{3}-\mathrm{N} \cdot \mathrm{gsmo}^{-1} \cdot \mathrm{d}^{-1}$ speed of the process. The DEPHANOX system also contributed to improvement of sludge sedimentation capacity (sludge index equaled $50 \mathrm{ml}^{-\mathrm{g}^{-1}}$ ).

The objective of our paper is to evaluate possibilities of removal of biogenic compounds using the denitrifying dephosphatation process in a treatment plant with nitrification separated on biofilters. This evaluation was carried out on the basis of data from one municipal sewage treatment plant in Swietokrzyskie voivodeship,
Poland, in which only a trickling filter technology is currently used as a biological component.

\section{Material and Methods}

\section{Sewage Treatment Plant Characteristics}

Results of municipal sewage treatment obtained in an exploited mechanical-biological sewage treatment plant in a Swietokrzyskie Voivodeship city were the basis for performed calculations. Sewage from about 14,000 citizens runs into the treatment plant. The designed sewage treatment plant capacity is $8620 \mathrm{~m}^{3} \cdot \mathrm{d}^{-1}$. The following objects are included in the technological chain of the analysed treatment plant: horizontal sand separator with manual sand removal, two Imhoff primary settling tanks, two submerged anoxic filters filled with BIOPEX packages (currently out of exploitation), two stage I trickling filters filled

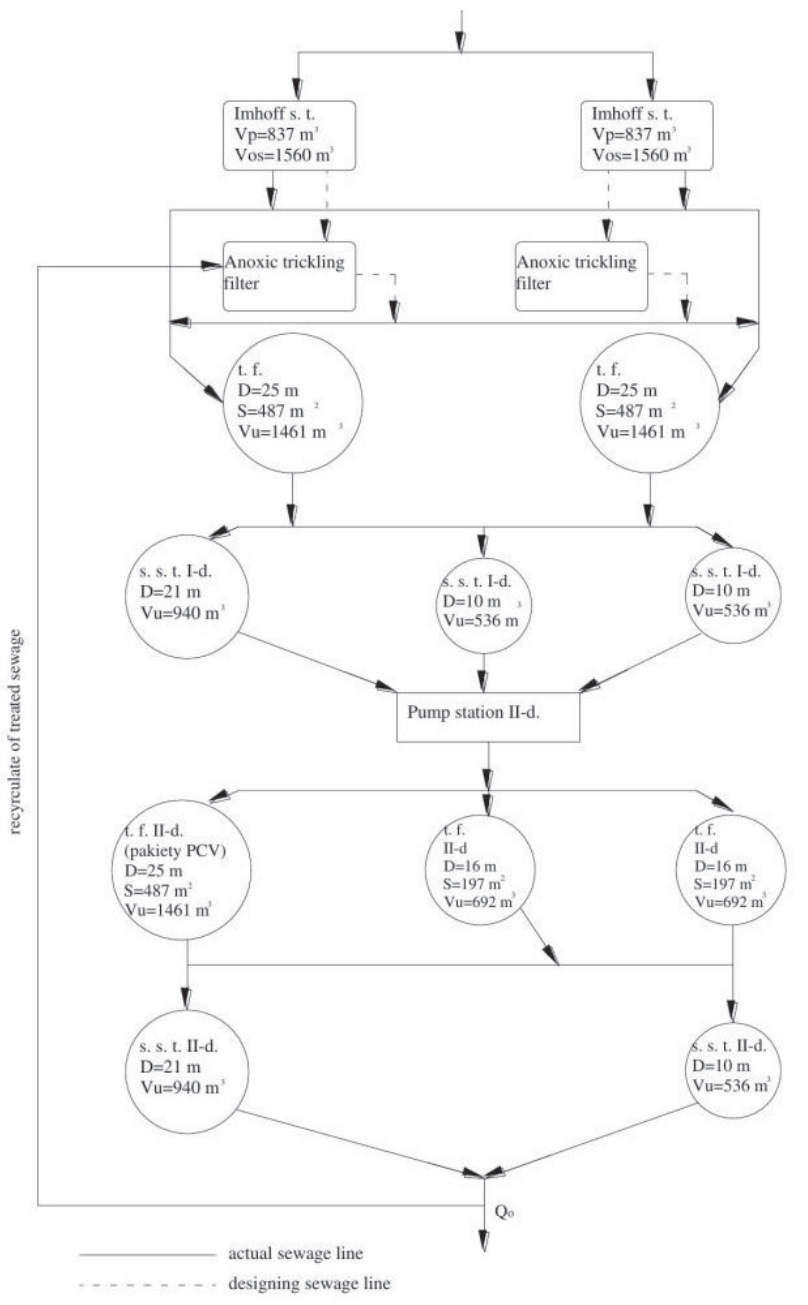

Fig. 1. Technological scheme of the analyzed sewage treatment plant: Imhoff s. t. - Imhoff settling tank; t. f. - trickling filter; s. s. t. I-d. - secondary settling tank first degree; Pump station II-d. - Pump station second degree; t. f. II-d. - trickling filter second degree; s. s. t. II-d. - secondary settling tank second degree 


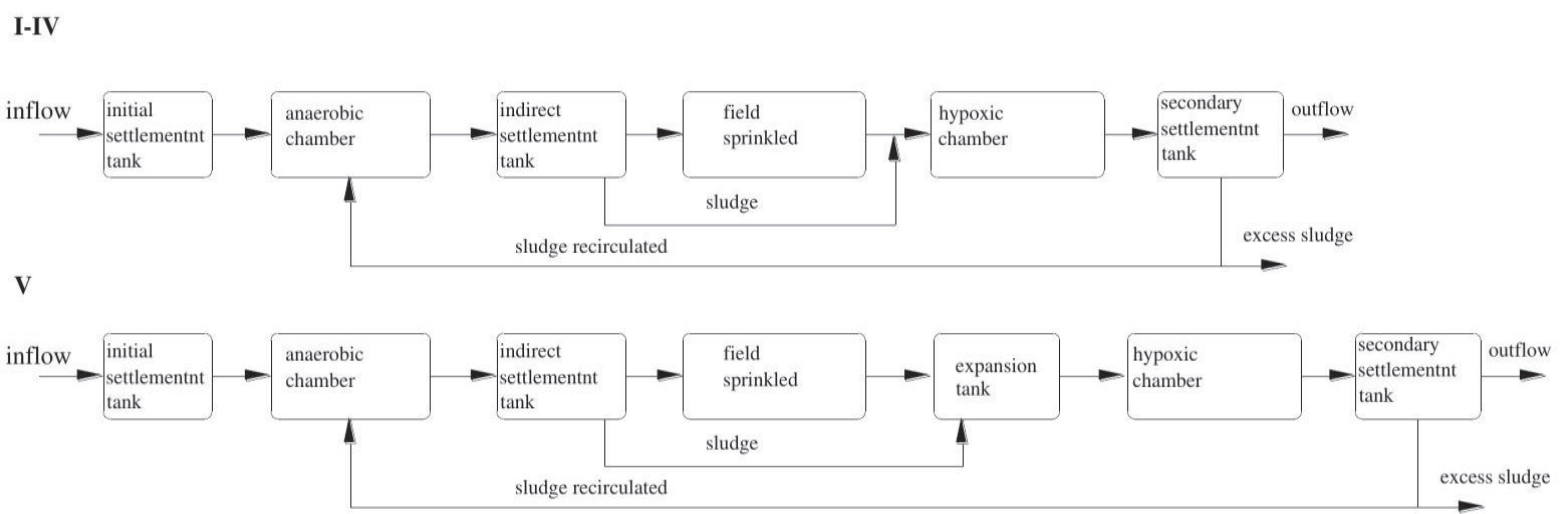

Fig. 2. Technological variants of the sewage treatment plant facilities included in the variant calculations.

with quartzite break stone of $80 \mathrm{~m}^{2} \cdot \mathrm{m}^{-3}$ active surface, three vertical intermediate settling tanks, a stage II sewage pump station, three stage II biofilters (two with quartzite break stone filling and one filled with BIOPEX packages), a coagulant PIX dosing station, and two stage II secondary settling tanks (vertical and radial; Fig. 1).

\section{Technological Variants of the Sewage Treatment Plant in Analysis}

In determining the configuration of each variant modernised in the future technological chain of sewage treatment, a principle of maximum use of objects that already exist in the treatment plant and a minimum dosage of chemicals was applied. Calculations were carried out for five technological variants (Fig. 2).

Differences in variants $\mathrm{I}-\mathrm{V}$ result from adopted values of anoxic chamber volume and oxygen concentration. In general, sewage treatment processes in the discussed variants run as follows: after initial treatment in the primary settling tank sewage goes to an anaerobic chamber where orthophosphates are released by bacteria cells. Energy to obtain and converse substrates (easily decomposable organic carbon) into polyhydroxyalkanoates, mainly poly- $\beta$ hydroxybutyrate, accumulated in PAO microorganism cells is derived from hydrolysis of cell polyphosphates. Subsequently, sewage runs into an intermediate settling tank, where residue is separated in the sedimentation process. Supernatant rich in orthophosphates and ammonium nitrogen with a small amount of organic matter is transferred to a trickling filter in which nitrification of ammonium nitrogen occurs. Sediment from the intermediate settling tank with PAO bacteria is transported to an anoxic chamber to which nitrified sewage from the biofilter, rich in nitrates, flows in. In the anoxic chamber with low oxygen concentration and the presence of nitrates as electron acceptors excessive intake of dissolved orthophosphates with simultaneous denitrification of nitrates takes place. The last element of the system is the secondary settling tank in which activated sludge is separated from the treated sewage by sedimentation. Treated sewage runs into the collector and sludge is partially recirculated to the anaerobic chamber, while the remainder is discharged outside the system as excess sludge.

Table 1 compares technical parameters of devices included in the analyzed variants. Equipment from the mechanical part of the sewage treatment plant, stage II of the biofilter with BIOPEX packages filling, and intermediate and secondary settling tanks from the previously exploited technological chain were left for operation, but stage I and II filters filled with quartzite break stone will be eliminated. Two existing chambers with submerged beds, which currently are not exploited, will be adapted as an anaerobic chamber. In proposed variants the anoxic chamber will be a new object created within modernization efforts. Although it was assumed that in the anoxic chamber denitrifying dephosphatation will occur, dissolved oxygen concentration was accepted to range from 0,5 to $1,0 \mathrm{mgO}_{2} \cdot \mathrm{dm}^{-3}$ for additional intake of phosphates remaining in the sewage by microorganisms.

\section{Experimental Procedure}

Calculations of pollution removal capacity in analyzed variants of the technological chain were based on commonly used mathematical models of pollutant transformation in bioreactors with activated sludge and biofilters. In recent years such an attitude is more and more common in the simulation of exploited treatment plants as well as in designing new technological systems of treatment. Processes related to wastewater treatment can be predicted using artificial neural networks (ANN), where the number of input variables can be separated by cluster analysis [24-26] or by principal component analysis [27, 28]. Activated sludge simulation models (ASIM) widely discussed in literature (e.g., by Gujer and Henze [29], Gujer and Larsena [30], Gujer et al. [31], Gujer et al. [32], Henze et al. [33], Snip et al. [34], and $\mathrm{Wu}$ et al. [35]) are leading in the modelling issues of operating systems with activated sludge. In the present paper calculations of activated sludge chambers 
Table 1. Technical characteristics of devices included in the analyzed variants.

\begin{tabular}{|c|c|c|c|c|c|}
\hline Device & \multicolumn{5}{|c|}{ Device characteristics } \\
\hline Variant & I & II & III & IV & $\mathrm{V}$ \\
\hline $\begin{array}{c}\text { Primary } \\
\text { settling tank }\end{array}$ & \multicolumn{5}{|c|}{$\begin{array}{l}\text { Settling tank volume } \mathrm{V}=837 \mathrm{~m}^{3} \text {; Depth of the flow part } \mathrm{H}=2,5 \mathrm{~m} ; \text { Amount of sludge/sewage }=0,20 \text {; } \\
\text { hydraulic load } \mathrm{O}_{\mathrm{h}}=13,44 \mathrm{~m}^{3} \cdot \mathrm{m}^{2} \cdot \mathrm{d}^{-1}\end{array}$} \\
\hline $\begin{array}{l}\text { Anaerobic } \\
\text { chamber }\end{array}$ & \multicolumn{5}{|c|}{ Oxygen concentration $\mathrm{O}_{2}=0,0 \mathrm{mg} \cdot \mathrm{dm}^{3}$; Chamber volume $\mathrm{V}=100 \mathrm{~m}^{3}$; Retention time $\mathrm{T}_{\mathrm{h}}=0,4 \mathrm{~h}$. } \\
\hline $\begin{array}{l}\text { Intermediate } \\
\text { settling tank }\end{array}$ & \multicolumn{5}{|c|}{ Amount of sludge $/$ sewage $=0,60$} \\
\hline Trickling filter & \multicolumn{5}{|c|}{$\begin{array}{c}\text { BIOPEX packages; Specific surface } A=150 \mathrm{~m}^{2} \cdot \mathrm{m}^{3}, \text { Filter volume } \mathrm{V}=1460 \mathrm{~m}^{3} \text {, Oxygen concentration } \mathrm{O}_{2}=2,0 \\
\mathrm{mg} \cdot \mathrm{dm}^{3}\end{array}$} \\
\hline $\begin{array}{l}\text { Anoxic } \\
\text { chamber }\end{array}$ & $\begin{array}{l}\text { Volume } \mathrm{V}=400 \mathrm{~m}^{3} \text {; } \\
\text { Oxygen concentra- } \\
\text { tion } \mathrm{O}_{2}=0,8 \mathrm{mg} \cdot \mathrm{dm}^{3} \text {; } \\
\text { Depth } \\
\mathrm{H}=4,0 \mathrm{~m}\end{array}$ & $\begin{array}{l}\text { Volume } \mathrm{V}=400 \mathrm{~m}^{3} \\
\text { Oxygen concentration } \\
\mathrm{O}_{2}=0,5 \mathrm{mg} \cdot \mathrm{dm}^{3} \\
\text { Depth } \mathrm{H}=4,0 \mathrm{~m}\end{array}$ & $\begin{array}{l}\text { Volume } \mathrm{V}=1000 \mathrm{~m}^{3} \\
\text { Oxygen concentration } \\
\mathrm{O}_{2}=0,8 \mathrm{mg} \cdot \mathrm{dm}^{3} \\
\text { Depth } \mathrm{H}=4,0 \mathrm{~m}\end{array}$ & $\begin{array}{l}\text { Volume } \mathrm{V}=1000 \mathrm{~m}^{3} \\
\text { Oxygen concentration } \\
\mathrm{O}_{2}=0,5 \mathrm{mg} \cdot \mathrm{dm}^{3} \\
\text { Depth } \mathrm{H}=4,0 \mathrm{~m}\end{array}$ & $\begin{array}{l}\text { Volume } \mathrm{V}=600 \mathrm{~m}^{3} \text {; } \\
\text { Oxygen concentration } \\
\mathrm{O}_{2}=1,0 \mathrm{mg} \cdot \mathrm{dm}^{3} \\
\text { Depth } \mathrm{H}=4,0 \mathrm{~m}\end{array}$ \\
\hline $\begin{array}{l}\text { Secondary } \\
\text { settling tank }\end{array}$ & \multicolumn{5}{|c|}{$\begin{array}{c}\text { Volume } \mathrm{V}=1880 \mathrm{~m}^{3} ; \text { Depth } \mathrm{H}=4,0 \mathrm{~m} ; \text { Hydraulic load } \mathrm{O}_{\mathrm{h}}=9,74 \mathrm{~m}^{3} \cdot \mathrm{m}^{2} \cdot \mathrm{d}^{-1} \\
\text { Sediment load } \mathrm{O}_{\mathrm{o}}=4,77 \mathrm{~kg} \cdot \mathrm{m}^{-2} \cdot \mathrm{d}^{-1} ; \text { Amount of sludge } / \text { sewage }=0,20 \\
\text { Reactive settling tank }\end{array}$} \\
\hline
\end{tabular}

were based on the ASIM 2d model, which represents continuation of the previous version called ASIM 2 [3638]. This takes into account dissolved substance, which consists of fermentation products, sewage alkalinity, very easily and easily decomposable organic matter, nitrogen dioxide as denitrification product, ammonium and ammonium nitrogen, nitrite and nitrate nitrogen, dissolved oxygen, and inorganic phosphates. This model also includes non-dissolved substances such as nitrifying organisms, heterotrophic aerobic and facultative anaerobic organisms, indecomposable molecular organic substance, salts and metal hydroxides (included in processes of chemical phosphorus precipitation), PAO phosphate-accumulating bacteria, cell components of bacteria (e.g., poly- $\beta$-hydroxybutyrates, polyphosphates, and slowly decomposable hydrolysed organic substances), and general suspended solids [39].

ASIM 2d model considers 21 unitary processes qualified into 5 groups: hydrolysis, processes with heterotrophic bacteria, processes with autotrophic bacteria, polyphosphate-accumulating bacteria, and chemical processes. A mathematical description of denitrification processes with polyphosphateaccumulating bacteria [40] was included in this model. The simulative calculation of activated sludge chambers was realised using BioWin 2 software. To realise the objective of the research, a model of pollutants' transformation on biofilter, described in Rauch's et al. paper [41], was also included in the ASIM 2d model, which consists of the following assumptions: biological membrane is of homogenous structure and density throughout the depth, microorganisms are uniformly distributed in the biological membrane, reactions occur with first-order kinetics, and dissolved substances are immediately diffused by biological membrane. The transformation of organic matter and nitrification of ammonium nitrogen in biological membrane were calculated according to the scheme given by Henze et al. [42].

Results of exploitation research on the objective treatment plant (which included average daily sewage inflow, $\mathrm{pH}$ reaction, $\mathrm{COD}$ values (total and dissolved), total suspended solids, Kiejdahl's general nitrogen, nitrate nitrogen, general phosphorus, and alkalinity) were adopted as input parameters for calculations. Sewage composition was determined by referential methods stated by Polish standards, as at work [43]. The description of shares of each organic fraction of pollutants in raw sewage has particular meaning in modelling of sewage treatment processes. In order to do this, analyses of total and dissolved COD content (after filtering through a filter of $0,45 \mu \mathrm{m}$ pore size) in raw sewage were performed, and then a share of each fraction was defined according to methods described by Barnad and Oleszkiewicz [44]. The age of sludge at $10 \mathrm{~d}$ and constant temperature at $\mathrm{T}=20^{\circ} \mathrm{C}$ were adopted for calculations. Constants of reaction kinetics were adopted from the range given by Henze et al. [33], Rauch et al. [41], and Henze et al. [42]; therefore, the obtained results can only illustrate the potential possibility of adaptating the existing biofilters into the chain with activated sludge. All simulations were performed in set conditions.

\section{Results and Discussion}

\section{Reducing Wastewater Pollutants}

The main reason why variant calculations of technological chains of the sewage treatment plant were undertaken was because the treated sewage did not meet conditions from water law permission for the objective treatment plant for general nitrogen and general 
Table 2. Share of each COD fraction in sewage running into the treatment plant .

\begin{tabular}{|c|c|}
\hline COD fraction & Value, $\mathrm{mg} / \mathrm{dm}^{3}$ \\
\hline Dissolved decomposable $\mathrm{S}_{\mathrm{BS}}$ & 110,53 \\
\hline Dissolved indecomposable $\mathrm{S}_{\mathrm{US}}$ & 34,54 \\
\hline Molecular decomposable $\mathrm{S}_{\mathrm{BP}}$ & 456,92 \\
\hline Molecular indecomposable $\mathrm{S}_{\mathrm{UP}}$ & 89,81 \\
\hline
\end{tabular}

phosphorus concentrations, which was confirmed by the statistical analysis of the obtained results. The calculations showed that, concerning $\mathrm{BOD}_{5}$ values, the treatment plant operates correctly for $66,2 \%$ of year, for COD $99,4 \%$, for total suspended solids $98,6 \%$, for general nitrogen $3,0 \%$, and for general phosphorus $89,8 \%$ [42]. Considering the insufficient capacity of sewage treatment concerning the removal of biogenic compounds, variant deliberations were carried out to search for the optimal solution of a technological chain that would guarantee reliable operation of the object regarding nitrogen and phosphorus removal from the sewage while enabling maximum usage of the existing objects. As shown by Bugajski and Woźniak-Vecchie [43] and Bugajski [44], there is a need to modify classical technological systems with activated sludge in order to intensify the process of biogenic compound removal.

\section{Experimental Procedure Results}

Table 2 presents average values of each COD fraction in raw sewage that were used for modeling.

Research showed that dissolved COD fraction constituted less than $21 \%$ of total COD, whereas the share of decomposable (dissolved and molecular) organic substances equaled $82 \%$ in total COD. This suggests that the analyzed sewage is susceptible to biochemical decomposition. Table 3 shows average values of the analyzed pollution indexes in the treated sewage obtained in performed calculations compared to values gained from the exploitation of the existing technological chain.

Calculations proved that in variants I-IV a lower treatment capacity was obtained for organic matter in comparison to the existing object. $\mathrm{BOD}_{5}$ values were significantly higher than the admissible level of $15 \mathrm{mgO} \cdot \mathrm{dm}^{-3}$. However, we observed that an increase in anoxic chamber volume from 400 to $1000 \mathrm{~m}^{3}$ and an increase of oxygen concentration from 0,5 to $0,8 \mathrm{mgO}_{2} \cdot \mathrm{dm}^{-3}$ causes an increase of organic pollutants' reduction. This results from the fact that although nitrified sewage after biofilter with low amount of organic pollutants flows into the anoxic chamber, it is still overloaded with organic matter from the residue after the intermediate settling tank. Calculations showed that the average $\mathrm{BOD}_{5}$ value in the sludge was $1117,9 \mathrm{mgO} \cdot \mathrm{dm}^{-3}$, and $\mathrm{COD} 2550,3 \mathrm{mgO} \cdot \mathrm{dm}^{-3}$. The high load of sludge with organic substances causes an increase of oxygen demand. Keeping low oxygen concentration in the anoxic chamber causes substrate to be only partially mineralised, which results in low $\mathrm{BOD}_{5}$ and COD production. It also results from low activity of activated sludge in the anoxic chamber - the calculated respiration speed for variants I and II ranged from 0,12 to $1,25 \mathrm{mgO}_{2} \cdot \mathrm{gsm}^{-1} \cdot \mathrm{h}^{-1}$, and for variants III and IV 7,54 and 9,67 $\mathrm{mgO}_{2} \cdot \mathrm{gsm}^{-1} \cdot \mathrm{h}^{-1}$, respectively. For total suspended solids a higher reduction obviously is observed in variants I-IV in comparison to the one obtained in the existing object. In each variant, concentrations of total suspended solids in the outflow were lower than the admissible value of $35 \mathrm{mg} \cdot \mathrm{dm}^{-3}$.

Introducing the anoxic chamber after nitrifying filters contributes to an increase of removal of general phosphorus from sewage. This is mainly caused by significant ammonium nitrogen reduction in the sewage in the nitrifying filter and its slight increase in the anoxic chamber. On the other hand, clear nitrate nitrogen reduction resulting from classic dissimilative denitrification is not observed (Fig. 3).

Table 3. Capacity of selected pollution indexes observed in exploited technological chain and calculated for analyzed variants.

\begin{tabular}{|c|c|c|c|c|c|c|c|}
\hline \multirow{2}{*}{ Pollution index } & \multirow{2}{*}{$\begin{array}{c}\text { Raw } \\
\text { sewage }\end{array}$} & \multirow{2}{*}{$\begin{array}{l}\text { Sewage treated in the } \\
\text { exploited treatment plant }\end{array}$} & \multicolumn{5}{|c|}{ Calculation variant } \\
\hline & & & I & II & III & IV & $\mathrm{V}$ \\
\hline \multirow{2}{*}{$\mathrm{BOD}_{5}, \mathrm{mgO}_{2} \cdot \mathrm{dm}^{-3}$} & \multirow{2}{*}{267,01} & $\underline{13,14^{*}}$ & $\underline{46,31}$ & $\underline{49,35}$ & $\underline{29,16}$ & $\underline{31,77}$ & $\underline{10,14}$ \\
\hline & & $95,1 * *$ & 82,6 & $\overline{81,5}$ & $\overline{89,1}$ & $\overline{88,1}$ & $\overline{96,2}$ \\
\hline \multirow{2}{*}{$\mathrm{COD}, \mathrm{mgO}_{2} \cdot \mathrm{dm}^{-3}$} & \multirow{2}{*}{690,83} & $\underline{55,25}$ & 77,24 & $\underline{80,89}$ & $\underline{52,33}$ & $\underline{58,52}$ & $\underline{35,9}$ \\
\hline & & 92,0 & 88,8 & 88,2 & 92,4 & 91,5 & 94,8 \\
\hline \multirow{2}{*}{ Total suspended solids $\mathrm{mg} \cdot \mathrm{dm}^{-3}$} & \multirow{2}{*}{209,23} & $\underline{18,51}$ & $\underline{2,84}$ & $\underline{0,98}$ & $\underline{1,05}$ & $\underline{1,21}$ & $\underline{4,49}$ \\
\hline & & 91,1 & $\overline{98,6}$ & $\overline{99,5}$ & $\overline{99,5}$ & 99,4 & $\overline{97,8}$ \\
\hline \multirow{2}{*}{ General nitrogen $\mathrm{mg} \cdot \mathrm{dm}^{-3}$} & \multirow{2}{*}{62,37} & 25,93 & 18,64 & 18,49 & 17,44 & 16,82 & $\underline{36,44}$ \\
\hline & & 58,4 & 70,1 & $\overline{70,3}$ & 72,0 & 73,0 & 41,6 \\
\hline \multirow{2}{*}{ General phosphorus $\mathrm{mg} \cdot \mathrm{dm}^{-3}$} & \multirow{2}{*}{9,03} & $\underline{3,39}$ & $\underline{3,13}$ & $\underline{3,14}$ & $\underline{3,07}$ & $\underline{2,9}$ & 1,74 \\
\hline & & 62,4 & 65,3 & 65,2 & 66,0 & 67,9 & 80,7 \\
\hline
\end{tabular}

\footnotetext{
*average concentration
}

$* *$ reduction, $\%$ 
In variants I-IV, general nitrogen concentration in the outflow is significantly lower than the one obtained in the real object; however, in each case the admissible value of $15 \mathrm{mg} \cdot \mathrm{dm}^{-3}$ is exceeded. In variants I-IV significant improvement of phosphorus removal in comparison to the existing treatment plant is not observed. Average concentrations of general phosphorus obtained from the calculations are slightly lower than the real values for the analyzed object and exceed the admissible value of $2,0 \mathrm{mg} \cdot \mathrm{dm}^{-3}$.

It is worth noting that phosphorus is removed only biologically in the analyzed variants, whereas in the existing treatment plant it is removed by chemical precipitation with PIX coagulant, dosed at the inflow to the stage II secondary settling tank. Therefore, possible modernization of the technological chain carried out accordingly to the discussed variants would contribute to lowering the costs of sewage treatment. Together with an increase of anoxic chamber volume and a decrease of dissolved oxygen concentration from 0,8 to $0,5 \mathrm{mgO}_{2} \cdot \mathrm{dm}^{-3}$, an increase of consumed phosphates can be noticed (Fig. 4). Considering the fact that in an anoxic chamber nitrate nitrogen occurred in a concentration of about $9,0 \mathrm{mgN}-\mathrm{NO}_{3} \cdot \mathrm{dm}^{-3}$, there was a possibility of denitrifying dephopsphatation, because $\mathrm{N}-\mathrm{NO}_{3}$ was the electron acceptor for PAO bacteria. On the other hand, the speed of phosphorus intake in the anoxic chamber could have been limited by insufficient nitrate nitrogen concentration and too short time of sewage retention.

The research carried out by Sorm et al. [14] showed that phosphates were partially consumed by PAO bacteria when initial concentration of $\mathrm{N}^{-\mathrm{NO}_{3}}$ equaled $25 \mathrm{mgN}-\mathrm{NO}_{3} \cdot \mathrm{dm}^{-3}$, whereas practically total phosphate intake occurred with initial $\mathrm{N}^{-\mathrm{NO}_{3}}$ concentration of $60 \mathrm{mgN}-\mathrm{NO}_{3} \cdot \mathrm{dm}^{-3}$ and lasted until their complete

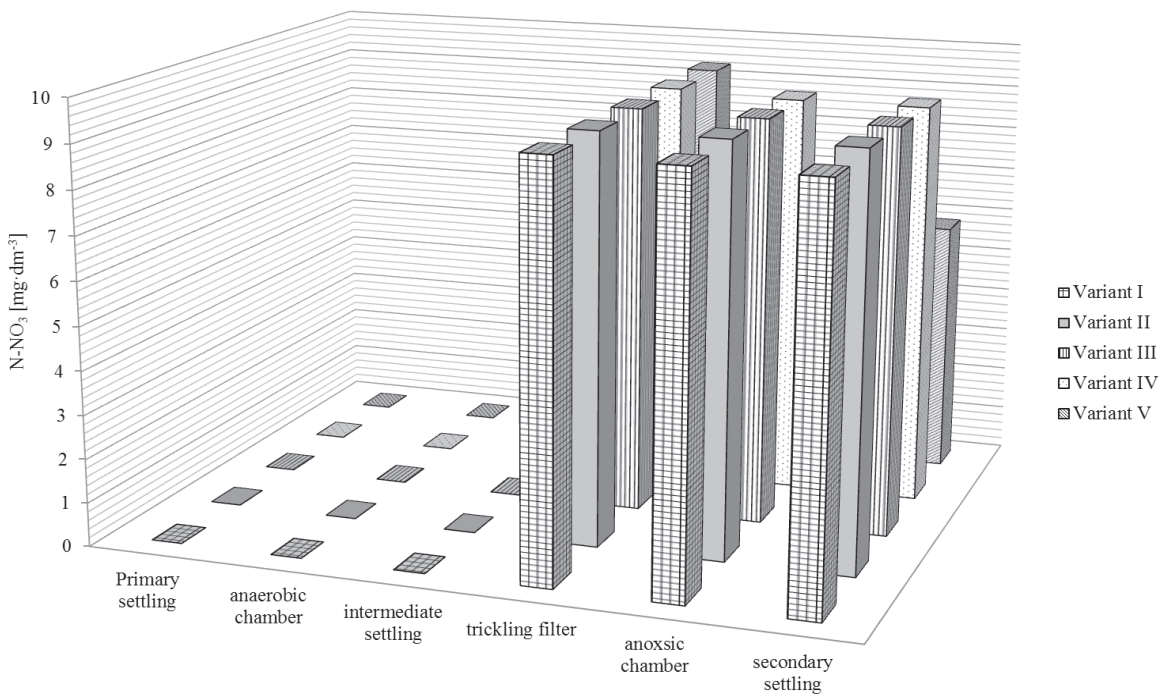

Fig. 3. Profile of concentration values of nitrate nitrogen for analyzed calculation variants.

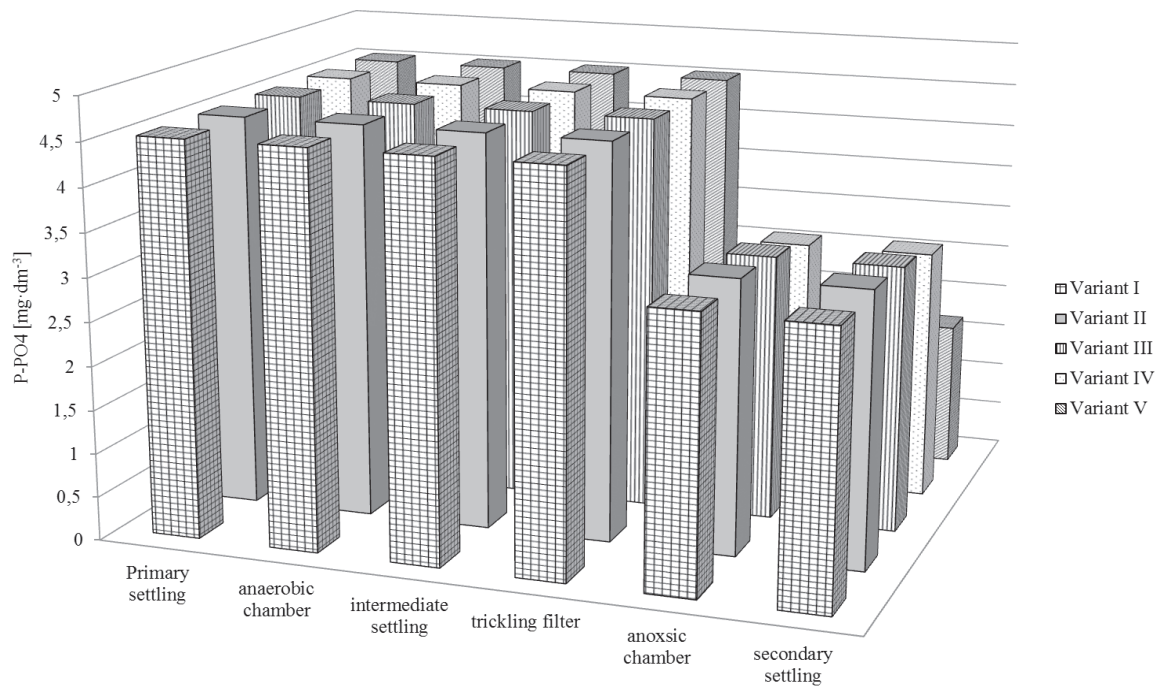

Fig. 4. Profile of concentration values of phosphates for analyzed calculation variants. 
depletion. $\mathrm{COD} / \mathrm{N}$ ratio confirms nitrate deficiency for denitrifying dephosphatation. As given by Kuba et al. [45], Chen et al. [49], and Meng et al. [50], optimum value of this ratio should amount to $3,5 \mathrm{gCOD} / \mathrm{gN}$. With a ratio higher than the given one (in the analyzed sewage it was 11,1), incomplete phosphorus removal occurs as caused by a deficiency of nitrates.

In variant $\mathrm{V}$ the volume of anoxic chamber was decreased to $600 \mathrm{~m}^{3}$ and oxygen concentration was increased to $1,0 \mathrm{mgO} \cdot \mathrm{dm}^{-3}$. As a result, significant improvement in organic pollutant removal was observed in comparison to variants I-IV. Average $\mathrm{BOD}_{5}$ and COD values at the outflow from the secondary settling tank were lower than the admissible value defined in the water-law permission. The concentration of total suspended solids slightly increased at the outflow in comparison to previously analyzed variants. General nitrogen reduction was significantly worse and its average concentration at the outflow reached $36,44 \mathrm{mg} \cdot \mathrm{dm}^{-3}$ and clearly exceeded value obtained in the existing object and admissible value from the water law permission. This situation is mainly caused by a significant increase of $\mathrm{N}^{-\mathrm{NH}_{4}}$ concentration in anoxic chamber to the level of $26,14 \mathrm{mgN}-\mathrm{NH}_{4} \cdot \mathrm{dm}^{-3}$. Increasing oxygen concentration in the anoxic chamber caused a decrease of the denitrification process, which in turn caused an increase in general nitrogen concentration at the outflow of the treatment plant. At the same time, such actions caused an increase of phosphorus consumed by PAO bacteria (general phosphorus concentration at the outflow of the settling tank was $1,74 \mathrm{mgP}_{\mathrm{og}} \cdot \mathrm{dm}^{-3}$ and does not exceed the admissible value). In the anoxic chamber bacteria do not have organic acids at their disposal so only organisms capable of using stored, easily decomposable substrates exclusively in the presence of nitrates as an electron acceptor are promoted [51].

\section{Conclusions}

As a result of the performed calculations, the following conclusions may be formulated:

1. It is possible to significantly remove organic pollutants $\left(\mathrm{BOD}_{5}, \mathrm{COD}\right)$ and total suspended solids from the sewage in a treatment plant with biofilters as biological stage devices. General phosphorus may be removed only by chemical precipitation.

2. There is a possibility of including biofilters into activated sludge technology in order to improve nitrogen and phosphorus removal from the sewage. The nitrification process will be carried out on biofilters, whereas in anaerobic and anoxic chambers operating in activated sludge technology the process of nitrogen and phosphorus removal will take place. Separating nitrifiers from heterotrophic organisms causes lack of competition between these organisms and higher stability of the nitrifier population. In systems with nitrification in the so-called "side sequence," a denitrifying dephosphatation process will be possible.

3. Using the denitrifying dephosphatation process reduces energy consumption of the system related to decreased oxygen need. Calculations showed that even with oxygen concentration of $1,0 \mathrm{mgO}_{2} \cdot \mathrm{dm}^{-3 i n}$ in an anoxic chamber, denitrification as well as orthophosphate intake were carried out by microorganisms.

4. The denitrifying dephosphatation process guarantees high general phosphorus removal at $81 \%$, provided that total easily decomposable substrate will be consumed by microorganisms in an anaerobic chamber and that a sufficient amount of phosphates will be available.

5. Calculations showed that integration of biofilters with activated sludge in a flow system allows for high reduction of organic pollutants, total suspended solids, and biogenic compounds from sewage. Considering general nitrogen reduction, the most favourable variant was the system with an anoxic chamber $1000 \mathrm{~m}^{3}$ in volume and oxygen concentration equal to $0,5 \mathrm{mgO}_{2} \cdot \mathrm{dm}^{-3}$, whereas phosphorus removal featured a solution with anoxic chamber $600 \mathrm{~m}^{3}$ in volume and oxygen concentration of $1,0 \mathrm{mgO}_{2} \cdot \mathrm{dm}^{-3}$.

6. The ASIM $2 \mathrm{~d}$ model seems to be an extremely useful tool for designing and simulating sewage treatment plant operation. It follows from the fact that it enables the simulation of most processes occurring in a bioreactor with activated sludge.

\section{Acknowledgements}

This research was financed by statutory activity of the Department of Sanitary Engineering and Water Management.

\section{Conflict of Interest}

The authors declare no conflict of interest

\section{References}

1. BUGAJSKI P., CHMIELOWSKI K., KACZOR G. Optimizing the percentage of sewage from septic tanks for stable operation of a wastewater treatment plant. Pol. J. Environ. Stud., 25 (4), 1421, 2016.

2. WAZSIK E., CHMIELOWSKI K. Ammonia and indicator bacteria removal from domestic sewage in a vertical flow filter filled with plastic material. Ecological Engineering, 106, 378, 2017.

3. MADEROVA Z., BALDIKOVA E., POSPISKOVA A., SAFARIK I., SAFARIKOVA M. Removal of dyes by adsorption on magnetically modified activated sludge. International Journal of Environmental Science and Technology, 13 (7), 1653, 2016. 
4. XIAO-MEI L., MING-FEI S., CHAO-LIN L., JI L., XINIEI G., FEI-YUN S. A comparative study of the bacterial community in denitrifying and traditional enhanced biological phosphorus removal processes. Microbes Environ., 29 (3), 261, 2014.

5. RUBIO-RINCÓN F., LOPEZ-VAZQUEZ C., WELLES L., VAN DEN BRAND T., ABBAS B., VAN LOOSDRECHT M., BRDJANOVIC D. Effects of electron acceptors on sulphate reduction activity in activated sludge processes. Appl. Microbiol. Biotechnol., 101, 6229, 2017.

6. WILFERT P., KUMAR P.S., KORVING L., WITKAMP G.J., VAN LOOSDRECHT M.C M. The relevance of phosphorus and iron chemistry to the recovery of phosphorus from wastewater: A review. Environ. Sci. Technol., 49, 9400, 2015.

7. SCHOUMANS O.F., BOURAOUI F., KABBE C., OENEMA O., VAN DIJK K.C. Phosphorus management in Europe in a changing world. Ambio, 44, 180, 2015.

8. HIROTA R., KURODA A., KATO J., OHTAKE H. Bacterial phosphate metabolism and its application to phosphorus recovery and industrial bioprocesses. J. Biosci. Bioeng., 109 (5), 423, 2010.

9. CÉDRIC T., HUU-THANH N., BROGNAUX A., DELEPIERRE A., DE CLERCQ L., CHARLIER R., MICHELS E., MEERS E., DELVIGNE F. Characterization of Phosphate Accumulating Organisms and Techniques for Polyphosphate Detection. A Review. Sensor, 16 (6), 797, 2016.

10. CAPODAGLIO A.G., HLAVÍNEK P., RABONI M. Advances in wastewater nitrogen removal by biological processes: state of art review. Ambiente \& Água - An Interdisciplinary Journal of Applied Science, 11 (2), 250, 2016.

11. NASEER R., ABDUALHAIL S., XIWU L. Biological nutrient removal with limited organic matter using a novel anaerobic-anoxic/oxic multi-phased activated sludge process. Saudi J. Biol. Sci., 20 (1), 11, 2013.

12. FUDALA-KSIĄŻEK S., KULBAT E., ŁUCZKIEWICZ A. Nitrification, denitrification, and dephosphatation capability of activated sludge during co-treatment of intermediate-age landfill leachates with municipal wastewater. Environmental Technology, 38, 1, 2017.

13. HUANG J., YANG P., LI C., GUO Y., LAI B., WANG Y., FENG L., ZHANG Y. Effect of nitre and nitrate concentrations on the performance of AFB-MFC enriched with high-strenght synthetic wastewater. Biotechnol. Res. Int. 2015, 798397, 2015.

14. TODT D., DORSCH P. Mechanism leading to $\mathrm{N}_{2} \mathrm{O}$ production in wastewater treating biofilm system. Rev. Environ. Sci. Biotechnol., 15 (3), 355, 2016.

15. COSKUN D., BRITTO D.T, SHI W., KRONZUCKER H.J. Nitrogen transformations in modern agriculture and the role of biological nitrification inhibition. Nature Plants, 6 , 17074, 2017.

16. RABONI M., TORRETTA V., VIOTTI P., URBINI G. Experimental plant for the physical-chemical treatment of groundwater polluted by municipal solid waste (MSW) leachate, with ammonia recovery. Revista Ambiente \& Agua, 8 (3), 22, 2013.

17. PRAMANIK B.K., FATIHAH S., SHAHROM Z., AHMED E. Biological aerated filters (BAFS) for carbon and nitrogen removal: a review. Journal of Engineering Science and Technology, 7 (4), 428, 2012

18. CAPODAGLIO A.G., HLAVÍNEK P., RABONI M. Advances in wastewater nitrogen removal by biologic al processes: state of the art review. An Interdisciplinary Journal of Applied Science, 11 (2), 250, 2016.

19. CAPODAGLIO A.G., HLAVÍNEK P., RABONI M. Advances in wastewater nitrogen removal by biologic al processes: state of the art review. An Interdisciplinary Journal of Applied Science, 11 (2), 250, 2016.

20. STYKA W. Evaluation of the contribution of denitrification dephosphatation in the removal of phosphorus in SBR reactors. Conference materials: Research, design and operation of sequential reactors, 35, Poland, 2004.

21. BORTONE G., SALTARELLI R., ALONSO V. SORM R., WANNER J., TILCHE A. Biological anoxic phosphorus removal - the DEPHANOX process. Water Science and Technology, 34 (1-2), 119, 1996.

22. KAPAGIANNIDIS A.G., ZAFIRIADIS I., AIVASIDIS A. Upgrading the efficiency of an external nitrification BNR system - the modified Dephanox process. The Chemical Engineering Journal, 175 (1), 124, 2011.

23. REN-JIAN D., JIN-SONG Z., ZHI-JUN Q. Characteristics of nitrogen and phosphorus removal in multiple postdenitrification process with different aeration rates. Journal of Residuals Science \& Technology, 13, 107, 2015.

24. WA̧SIK E., CHMIELOWSKI K., STUDZIŃSKI J., SZELĄG B. Use of artificial neural networks to predict selected forms of nitrogen in the outflow from wastewater treatment plants. Ochrona Środowiska (in press), 2018. [In Polish].

25. DÜRRENMATT D.J., GUJER W. Identification of industrial wastewater by clustering wastewater treatment plant influent ultraviolet visible spectra, 63 (6), 1153, 2011.

26. BAYO J., LÓPEZ-CASTELLANOS J. Principal factor and hierarchical cluster analyses for performance assessment of an urban wastewater treatment plant in the Southeast of Spain. Chemosphere, 155, 152, 2016.

27. WĄSIK, E., CHMIELOWSKI, K., OPERACZ A. PCA as a data mining tools characterizing the work of nitrification reactors in the sewage treatment plant in Trepcza. Acta Sci. Pol. Form. Cir., 16 (1), 209, 2017. [In Polish]

28. YANG Y., YU K., XIA Y., LAU F.T.K., TANG D.T.W., FUNG W.C., FANG H.H.P., ZHANG T. Metagenomic analysis of sludge from full-scale anaerobic digesters operated in municipal wastewater treatment plants. Applied Microbiology and Biotechnology, 98 (12), 5709, 2014.

29. GUJER W., HENZE M. Activated sludge modeling and simulation. Water Science and Technology, 23 (4-6), 1011, 1991.

30. GUJER W., LARSEN T.A. The implementation of biokinetic and conservation principles in ASIM. Water Science and Technology, 31 (2), 257, 1995.

31. GUJER W., HENZE M., MINO T., MATUSO T., WENTZEL M.C., MARAIS G.V.R. The Activated Sludge Model No 2. Biological phosphorus removal. Water Science and Technology, 31 (2), 1, 1995.

32. GUJER W., HENZE M., MINO T., VAN LOOSDRECHT M. Activated Sludge Model No 3. Water Science and Technology, 39 (1), 183, 1999.

33. HENZE M., GUJER W., MINO T., MATUSO T., WENTZEL M.C, MARAIS G.V.R., VAN LOOSDRECHT C.M. Activated Sludge Model No 2D, ASIM2D. Water Science and Technology, 39 (1), 165, 1999.

34. SNIP L.J.P., BOIOCCHI R., FLORES-ALSINA X., JEPPSSON U., GERNAEY K.V. Challenges encountered when expanding activated sludge models: a case study based on $\mathrm{N}_{2} \mathrm{O}$ production. Water Science Et Technology, 70 (7), 1251, 2014. 
35. WU X., YANGA Y., WU G., MAO J., ZHOU T. Simulation and optimization of a coking wastewater biological treatment process by activated sludge models (ASM). Journal of Environmental Management, 165, 235, 2016.

36. MACHADO V.C, LAFUENTE J., BAEZA J A. 2014. Activated sludge model $2 \mathrm{~d}$ calibration with full-scale WWTP data: comparing model parameter identifiability with influent and operational uncertainty. Bioprocess and Biosystems Engineering, 37 (7), 1271, 2014.

37. ALIKHANI J., TAKACS I., AL-OMARI A., MURTHY S., MASSOUDIEH A. Evaluation of the information content of long-term wastewater characteristics data in relation to activated sludge model parameters. Water Science Et Technology, 75 (6), 1370, 2017.

38. GUO L., VANROLLEGHEM P.A. Calibration and validation of an activated sludge model for greenhouse gases no. 1 (ASMG1): prediction of temperature-dependent $\mathrm{N}_{2} \mathrm{O}$ emission dynamics. Bioprocess and Biosystems Engineering, 37 (2), 151, 2014.

39. IKUMI D.S., HARDING T.H., EKAMA G. A. Biodegradability of wastewater and activated sludge organics in anaerobic digestion. Water Research, 56, 267, 2014.

40. MAKINIA J. Mathematical modeling and computer simulation of activated sludge system, 390, United Kingdom, 2010.

41. RAUCH W., VANHOOREN H.,. VANROLLEGHEM P.A. A simplified mixed-culture biofilm model. Water Research, 33 (9), 2148, 1999.

42. HENZE M., HARREMOËS P., JANSEN J., ARVIN E. Wastewater treatment. Biological and chemical processes. Publ. Kielce University of Technology, 359, Poland, 2002. [In Polish]

43. KACZOR G., BERGEL T., BUGAJSKI P., PIJANOWSKI J. Aspects of sewage disposal from tourist facilities in national park and other protected areas. Pol. J. Environ. Stud., 24 (1), 107, 2015.
44. BARNARD J.L., OLESZKIEWICZ J.A. Wastewater characteristics and examples of its impact on the size of the activated sludge chamber. Materials of the training seminar, 239, Poland, 2000.

45. KUBA T., LOOSDRECHT M., HEIJNEN J. Phosphorus and nitrogen removal with minimal COD requirement by integration of denitrifying dephosphatation and nitrification in two-sludge system. Water Research, 30 (7), 1702, 1996.

46. BUGAJSKI P., WOŹNIAK-VECCHIE R. influence of organic compounds on nitrogen removal processes in a small wastewater treatment plant. Gaz, Woda, Technika Sanitarna, 10, 354, 2011. [In Polish]

47. BUGAJSKI P. Assessment of nutrient removal reliability in a sewage treatment plant using the Weibull method. Zeszyty Problemowe Nauk Rolniczych, 276, 13, 2014. [In Polish]

48. KUBA T., LOOSDRECHT M., HEIJNEN J. Occurrence of denitrifying phosphorus removing bacteria in modified UCT-type wastewater treatment plants. Water Research, 31 (4), 777, 1997.

49. CHEN Y., LI B., YE L., PENG Y. The combined effects of $\mathrm{COD} / \mathrm{N}$ ratio and nitrate recycling ratio on nitrogen and phosphorus removal in anaerobic/anoxic/aerobic (A2/O)biological aerated filter (BAF) systems. Biochemical Engineering Journal, 93, 235, 2015.

50. MENG J., LI J., LI J., DENG K., NAN J., XU P. Effect of reflux ratio on nitrogen removal in a novel upflow microaerobic sludge reactor treating piggery wastewater with high ammonium and low $\mathrm{COD} / \mathrm{TN}$ ratio: Efficiency and quantitative molecular mechanism. Bioresource Technology, 243, 922, 2016.

51. DU D., ZHANG C., ZHAO K., SUN G., ZOU S., YUAN L., HE S. Effect of different carbon sources on performance of an A2N-MBR process and its microbial community structure. Front. Environ. Sci. Eng., 12 (2), 1, 2018. 